\title{
Front Matter: Volume 11350
}

, "Front Matter: Volume 11350," Proc. SPIE 11350, Digital Optics for Immersive Displays II, 1135001 (14 April 2020); doi: 10.1117/12.2571790

SPIE. Event: SPIE Photonics Europe, 2020, Online Only 


\title{
PROCEEDINGS OF SPIE
}

\section{Digital Optics for Immersive Displays II}

\author{
Bernard C. Kress \\ Christophe Peroz \\ Editors
}

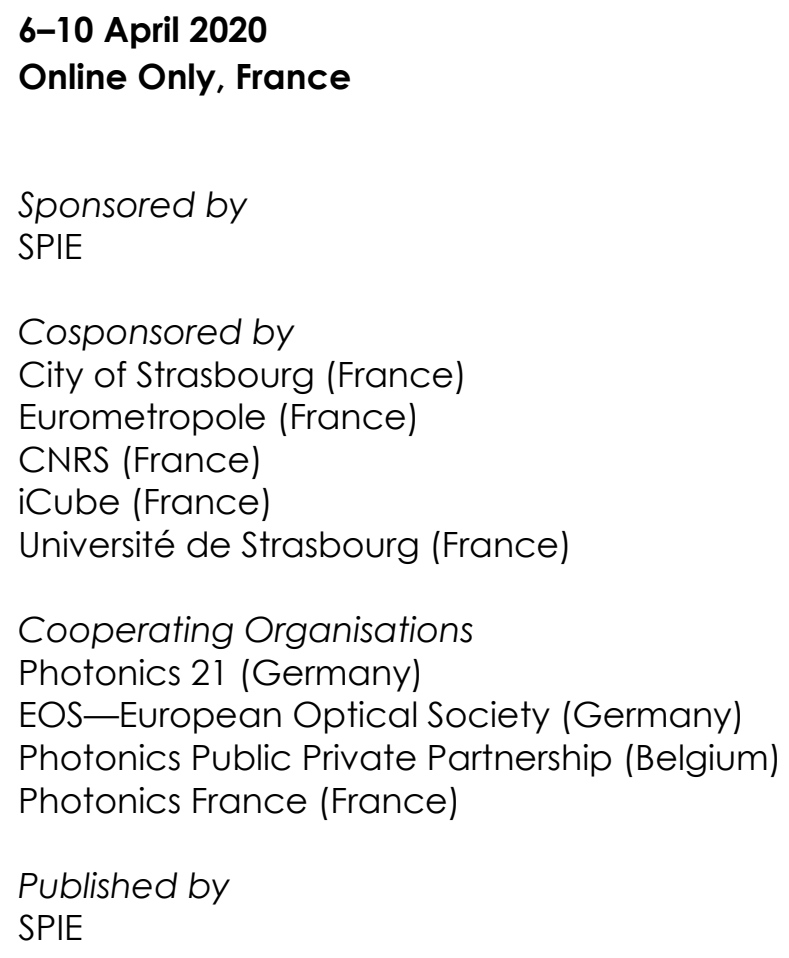


The papers in this volume were part of the technical conference cited on the cover and title page. Papers were selected and subject to review by the editors and conference program committee. Some conference presentations may not be available for publication. Additional papers and presentation recordings may be available online in the SPIE Digital Library at SPIEDigitalLibrary.org.

The papers reflect the work and thoughts of the authors and are published herein as submitted. The publisher is not responsible for the validity of the information or for any outcomes resulting from reliance thereon.

Please use the following format to cite material from these proceedings:

Author(s), "Title of Paper," in Digital Optics for Immersive Displays II, edited by Bernard C. Kress, Christophe Peroz, Proceedings of SPIE Vol. 11350 (SPIE, Bellingham, WA, 2020) Seven-digit Article CID Number.

ISSN: 0277-786X

ISSN: 1996-756X (electronic)

ISBN: 9781510634725

ISBN: 9781510634732 (electronic)

Published by

SPIE

P.O. Box 10, Bellingham, Washington 98227-0010 USA

Telephone +1 3606763290 (Pacific Time) · Fax +1 3606471445

SPIE.org

Copyright (C) 2020, Society of Photo-Optical Instrumentation Engineers.

Copying of material in this book for internal or personal use, or for the internal or personal use of specific clients, beyond the fair use provisions granted by the U.S. Copyright Law is authorized by SPIE subject to payment of copying fees. The Transactional Reporting Service base fee for this volume is $\$ 21.00$ per article (or portion thereof), which should be paid directly to the Copyright Clearance Center (CCC), 222 Rosewood Drive, Danvers, MA 01923. Payment may also be made electronically through CCC Online at copyright.com. Other copying for republication, resale, advertising or promotion, or any form of systematic or multiple reproduction of any material in this book is prohibited except with permission in writing from the publisher. The CCC fee code is 0277$786 \mathrm{X} / 20 / \$ 18.00$.

Printed in the United States of America by Curran Associates, Inc., under license from SPIE.

Publication of record for individual papers is online in the SPIE Digital Library.

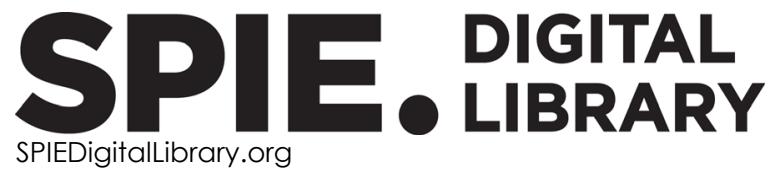

Paper Numbering: Proceedings of SPIE follow an e-First publication model. A unique citation identifier (CID) number is assigned to each article at the time of publication. Utilization of CIDs allows articles to be fully citable as soon as they are published online, and connects the same identifier to all online and print versions of the publication. SPIE uses a seven-digit CID article numbering system structured as follows:

- The first five digits correspond to the SPIE volume number.

- The last two digits indicate publication order within the volume using a Base 36 numbering system employing both numerals and letters. These two-number sets start with $00,01,02,03,04$, 05, 06, 07, 08, 09, OA, OB ... 0Z, followed by 10-1Z, 20-2Z, etc. The CID Number appears on each page of the manuscript. 


\title{
Contents
}

\author{
$\checkmark \quad$ Authors \\ vii Conference Committee
}

\section{SESSION $1 \quad$ DIGITAL OPTICS FOR AR AND VR SYSTEMS}

1135002 Effects of polarisation and spatial coherence in the pupil expansion with crossed gratings in an AR display [11350-1]

1135004 Double-pass HOE operation for compact AR glasses design [11350-4]

1135005 Wide-field-of-view augmented reality eyeglasses using curved wedge waveguide [1 1350-5]

SESSION 2 DIGITAL OPTICS FABRICATION AND TESTING FOR IMMERSIVE DISPLAYS

1135006 Curved microdisplay, from optical design to mechanical study: impact on form-factor and light efficiency in visual systems (Invited Paper) [11350-6]

1135008 Evaluation of augmented reality (AR) displays performance based on human visual perception [11350-8]

SESSION 3 DIGITAL OPTICS FOR 3D IMAGING AND 3D DISPLAY

11350 OA XSlit cameras for free navigation with depth image-based rendering [11350-10]

11350 OC EEG based assessment of user performance for a volumetric multiplanar display [11350-13]

\section{ADDITIONAL PRESENTATIONS}

11350 OE Wide field of view HOE-based waveguides system for AR display [1 1350-14]

11350 OF Tunable lens for AR headset [1 1350-15] 
Proc. of SPIE Vol. $113501135001-4$ Downloaded From: https://www.spiedigitallibrary.org/conference-proceedings-of-spie on 26 Apr 2023
Terms of Use: https://www.spiedigitallibrary.org/terms-of-use 


\title{
Authors
}

\begin{abstract}
Numbers in the index correspond to the last two digits of the seven-digit citation identifier (CID) article numbering system used in Proceedings of SPIE. The first five digits reflect the volume number. Base 36 numbering is employed for the last two digits and indicates the order of articles within the volume. Numbers start with 00, 01, 02, 03, 04, 05, 06, 07, 08, 09, 0A, OB...0Z, followed by 10-1Z, 20-2Z, etc.
\end{abstract}

Angervaks, Aleksandr, OE

Borisov, Vladimir N., OE, OF

Charrière, S., 06

Danilova, Svetlana $\mathrm{V}$., $\mathrm{OE}, \mathrm{OF}$

de Cunsel, Sébastien, 08

Fachada, Sarah, OA

Gan, Choon How, 02

Golos, Anna, 02

Haeberle, $0 ., 06$

Henry, D., 06

Joly, P. L., 06

Kalinina, Anastasiia, 04, 05

Kleemann, Marie-Elena, 02

Krumina, Gunta, OC

Lafruit, Gauthier, OA

Lvova, Kseniia, 04

Muravev, Nikolay, OE

Naderi, Mehrdad, OC

Nicolas, S., 06

Okun, Roman, OE

Perevoznikova, Anastasiia, 04

Piskunov, Dmitry E., OF

Pladere, Tatjana, OC

Popov, Mikhail V., OE, OF

Putilin, Andrey N., 04, 05, OE

Simon, B., 06

Tigaev, Vladislav O., OF

Valera, Salim, 02

Vostrikov, Gavril, OE

Zuber, F., 06 
Proc. of SPIE Vol. $113501135001-6$ Downloaded From: https://www.spiedigitallibrary.org/conference-proceedings-of-spie on 26 Apr 2023
Terms of Use: https://www.spiedigitallibrary.org/terms-of-use 


\section{Conference Committee}

Symposium Chairs

Francis Berghmans, Vrije Universiteit Brussel (Belgium)

Thierry Georges, Oxxius SA (France)

Paul Montgomery, Université de Strasbourg (France)

Lluis Torner, ICFO Barcelona (Spain)

Conference Chairs

Bernard C. Kress, Microsoft Corporation (United States)

Christophe Peroz, Magic Leap, Inc. (United States)

Conference Programme Committee

Tibor Balogh, Holografika Kft. (Hungary)

Christian Bosshard, Centre Suisse d' Electronique et de Microtechnique SA (Switzerland)

Federico Capasso, Harvard School of Engineering and Applied Sciences (United States)

Dan Curticapean, Hochschule Offenburg (Germany)

Arie den Boef, ASML Netherlands B.V. (Netherlands)

Andreas Hermerschmidt, HOLOEYE Photonics AG (Germany)

Hong Hua, James C. Wyant College of Optical Sciences

(United States)

Norbert Kerwien, Carl Zeiss AG (Germany)

Stan Larroque

Byoungho Lee, Seoul National University (Korea, Republic of)

Scott McEldowney, Oculus VR, LLC (United States)

Darran Milne

Juan C. Miñano, Limbak 4PI S.L. (Spain)

Ilmars Osmanis, Lightspace Technologies, SIA (Latvia)

Silvania F. Pereira, Technische Universiteit Delft (Netherlands)

Pascal Picart, Le Mans Université (France)

Demetri Psaltis, Ecole Polytechnique Fédérale de Lausanne

(Switzerland)

Monika Ritsch-Marte, Medizinische Universität Innsbruck (Austria)

Peter Schelkens, Vrije Universiteit Brussel (Belgium)

Robert Stevens, Adlens Ltd (United Kingdom)

Hagen Stolle, SeeReal Technologies GmbH (Germany)

Hugo Thienpont, Vrije Universiteit Brussel (Belgium)

Reinhard Voelkel, SUSS MicroOptics SA (Switzerland) 


\section{Session Chairs}

1 Digital Optics for AR and VR Systems

Bernard C. Kress, Microsoft Corporation (United States)

2 Digital Optics Fabrication and Testing for Immersive Displays Christophe Peroz, Magic Leap, Inc. (United States)

3 Digital Optics for 3D Imaging and 3D Display

Maria Pace, Microsoft Corporation (United States) 